\title{
MATHEMATICAL MODEL FOR ERRORS ESTIMATION OF OBJECT'S LOCATION PARAMETERS DETERMINATION USING FLYING PLATFORM
}

\author{
Korolov Volodimir ${ }^{1}$, Savchuk Stepan ${ }^{2}$, Korolova Olha1, Milkovich Ihor ${ }^{1}$, Zaec Yaroslav ${ }^{1}$ \\ ${ }^{1}$ National Academy of Land Forces named after Hetman Petro Sakhajdachnyj, Ukraine \\ ${ }^{2}$ Lviv Polytechnic National University, Ukraine
}

\begin{abstract}
.
Some tasks require identification of landmarks in districts beyond the reach of existing optical observation facilities. The accuracy of their determination significantly affects the effectiveness of the use necessary equipment during the task.

In the paper an algorithm to determine the object parameters using a flying platform is offered. An observation point is installed which is equipped with a navigation system to solve this task. This ensures its orientation and positioning.

From the observation point an aerial observation point is displayed. It is suggested to use a flying platform. The coordinates of the flying platform are determined relative to the observation point, the coordinates of the landmarks are determined relative to the flying platform. The mathematical model of the estimation error determination of object coordinates with the help of a flying platform is proposed.

The analysis of errors in determining the parameters of the object using a flying platform is conducted. Analysis of the results of mathematical modeling is conducted using the package of applications Mathcad. The dependence of these parameters on the relative position of the observation point, platforms and object is examined.

It is shown that the main contribution to the error of determining the coordinates of the landmark is given by the errors of determining the observation point location and measuring the range. An analytical correlation is obtained, which allows to estimate the errors of determining the coordinates of the landmark using the flying platform with known errors in determining the observation point coordinates and the range determination of the range finder.

Keywords: object parameters, flying platform, the estimation.
\end{abstract}

\section{Introduction}

Actuality of theme. The accuracy of determining the landmark parameters significantly affects the effectiveness of the use necessary equipment during the task.

Some tasks require identification of landmarks in districts beyond the reach of existing optical observation facilities. For example, if, under the terrain conditions, it is impossible to determine the parameters of the landmark, which is not observed from the observation point.

Analysis of research and publications. An analysis of modern research and publications shows that in most works (Korolov et.al., 2011; Korolov et.al., 2009; Korolov et.al., 2009) tasks on a plane are solved. Approaches are considered for the estimation of the influence of distances to the reference and directional angle, which can be used only within the direct vision.

Formulation of the problem. Since there is a need to act outside that is available to existing optical observation means, the application of the flying platform is one option for solving this problem.

In this case, there is the task of determining the object parameters with the help of additional equipment, which should be located at the observation point and on the flying platform, as well as the evaluation of the accuracy of their determination.

Unresolved part of the common problem. To date, there is no definition:

- list of the object parameters, which are to be found, using the flying platform;

- algorithm of their definition.

No estimation errors have been made in determining the object parameters defined by flying platform. Setting objectives. Analyze the errors that occur when determining the object coordinates using the flying platform.

\section{Methodology of research and materials}

The article investigates the effect of errors in measuring angles and distances on the estimation in determining the landmark coordinates. Coordinate variance is considered as an estimate of the 
determination error (as a function of many random arguments) using well-known relations in probability theory.

Dependencies of coordinates determination errors on measurement errors (which are assumed to be measured normally) are investigated using the Mathcad software package.

\section{Discussions and results}

Often the definition of the object location is executed from the top geodesically unprepared points. To solve this, an observation point is installed which is equipped with a navigation system. This ensures its orientation and determination of coordinates. From the observation point, an aerial observation point is displayed, in which it is proposed to use a flying platform. The coordinates of the flying platform are determined relative to the observation point, the object coordinates are determined relative to the flying platform (Fig. 1).

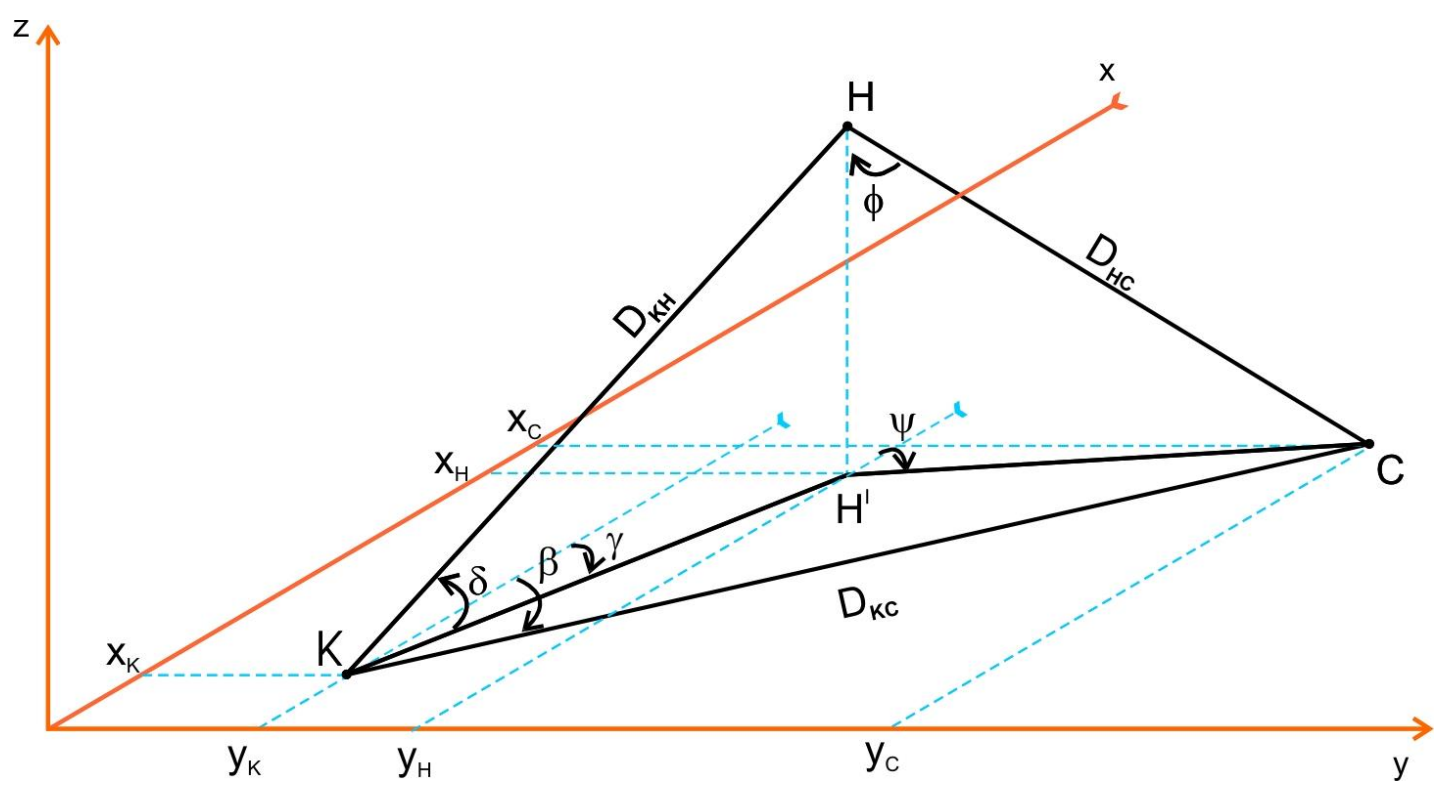

Fig. 1. Calculation of the landmark coordinates using the flying platform

The following symbols are used in the figure 1:

$\mathrm{K}$ is the observation point;

$\mathrm{H}$ - the flying platform;

$\mathrm{C}$ - the object;

$x_{k}, y_{k}$ - the coordinates of the observation point;

$x_{h}, y_{h}$ - the coordinates of the flying platform;

$x_{c}, y_{c}$ - the coordinates of the object;

$D_{K H}$ - the distance between observation point and flying platform;

$D_{H C}$ - the distance between the flying platform and the object;

$D_{K C}$ - the distance between the observation point and the object;

$\beta$ - the directional angle of reference;

$\delta$ - the angle between the horizon and the direction from the observation point to the flying platform; $\gamma$ - the angle between the vertical line of the map grid and the horizontal distance projection from the flying platform to the observation point;

$\varphi$ - the angle between the vertical passing through the flying platform and the direction from the flying platform to the object;

$\psi$ - the angle between the vertical line of the map grid and the distance projection from the flying platform to the object on the plane of the horizon.

As an alternative, consider determining of the object coordinates using the flying platform. The object coordinates $x_{c}, y_{c}$, we obtain from the correlation: 


$$
\begin{aligned}
& x_{c}=x_{k}+D_{K H} \cos \delta \cos \gamma+D_{H C} \sin \varphi \cos \psi, \\
& y_{c}=y_{k}+D_{K H} \cos \delta \sin \gamma+D_{H C} \sin \varphi \sin \psi
\end{aligned}
$$

Values $x_{c}, y_{c}$ are functions of many variables, which in their composition contain errors of a random nature. Thus, these functions can be considered as functions of many random variables. Then, for the errors of their definition, it is advisable to take their dispersion. It is known that the variance of the function $f(\bar{X})$ of random arguments can be calculated by the expression (Ventcel, 1969):

$$
\sigma_{f}^{2}=\sum_{i=1}^{N}\left(\frac{\partial f}{\partial x_{3}}\right)^{2} \sigma_{x_{i}}^{2}
$$

where: $f$ - the function of random arguments;

$\mathrm{N}$ - number of variables (in our case, 8 );

$\bar{X} \equiv\left\{x_{i}, \ldots, x_{n}\right\}$ - vector of independent variables (in our case $\left.x_{k}, y_{k}, D_{K H}, D_{H C} \delta, \gamma, \varphi, \psi\right)$;

$\sigma_{x_{i}}^{2}-$ variance of the $\mathrm{i}$-th independent variable.

Applying (2) to (1) and taking into account that measurements of linear and angular variables on the observation point and platform are determined with the same accuracy, respectively $\sigma_{D_{K H}}^{2}=\sigma_{D_{H C}}^{2} \equiv \sigma_{D}^{2}, \sigma_{\delta}^{2}=\sigma_{\gamma}^{2}=\sigma_{\varphi}^{2}=\sigma_{\psi}^{2} \equiv \sigma_{\theta}^{2}$, and the radial error is $\sigma_{r_{K}}^{2}=\sigma_{x_{K}}^{2}+\sigma_{y_{K}}^{2}$, then for the estimation of the radial error of the orientation of the coordinates we obtain the following expression:

$$
\sigma_{r_{C}}^{2}=\sigma_{r_{K}}^{2}+\sigma_{D}^{2}\left(\cos ^{2} \delta+\sin ^{2} \varphi\right)+\sigma_{\theta}^{2}\left(D_{K H}^{2}+D_{H C}^{2}\right) .
$$

We will investigate the behavior of the 1 st, 2 nd and 3 rd additions on the right side of the equation number 3.

The horizontal range to the flying platform $\left(K H^{\prime}\right)$ denote for 'A', and the horizontal distance from the flying platform to the object $\left(H^{\prime} C\right)$ denote for 'B'. We will consider the most typical variants of location the observation point, flying platform and the object.

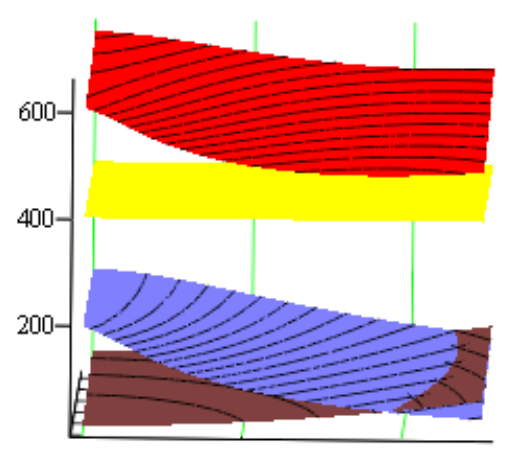

$\mathrm{A}-3000 \mathrm{M}$

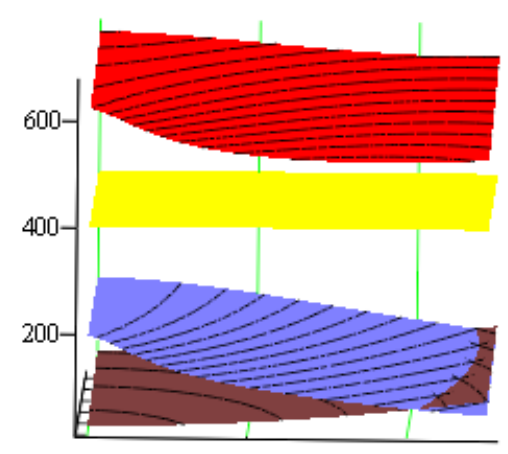

$\mathrm{A}-5000 \mathrm{M}$

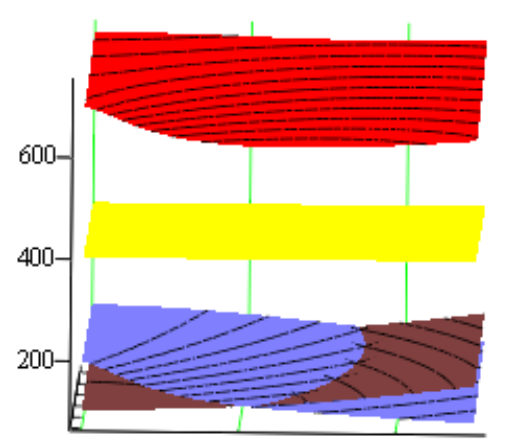

$\mathrm{A}-10000 \mathrm{M}$

Fig. 2. Dependence of component values $\sigma_{r_{C}}^{2}$ from height of the flying platform and range $D_{H C}$

Mathematical modeling was conducted using the package of applications Mathcad. Analysis of the results of mathematical modeling presented in Fig. 2. It shows that the term, $\sigma_{D}^{2}\left(\cos ^{2} \delta+\sin ^{2} \varphi\right)$ (it is shown in the picture in blue color) - varies from $0 \div 190$. The component of the right-hand side expression number (3) equation $\sigma_{\theta}^{2}\left(D^{2}{ }_{K H}+D^{2}{ }_{H C}\right)$ (it is shown in brown) is an order less than 
$\sigma_{D}^{2}\left(\cos ^{2} \delta+\sin ^{2} \varphi\right)$. We can conclude - the error of the observation point location $\sigma_{r_{K}}^{2}$ (it is shown in yellow) is the main element of the total error $\sigma_{r_{C}}^{2}$ (it is shown in red). The constituent $\sigma_{D}^{2}\left(\cos ^{2} \delta+\sin ^{2} \varphi\right)$ is less important, the value of the third term is one order less than the first, and therefore it can be neglected. Then the analytic dependence number (3) takes on the following form:

$$
\sigma_{r_{C}}^{2}=\sigma_{r_{K}}^{2}+\sigma_{D}^{2}\left(\cos ^{2} \delta+\sin ^{2} \varphi\right) .
$$

This correlation allows us to estimate the accuracy of determining the object coordinates using the flying platform, if known $\sigma_{r_{K}}^{2}$ and $\sigma_{D}^{2}$.

Take the typical navigation system, the error of which $\sigma_{r_{K}}$ is about $20 \mathrm{~m}$, and according to the technical characteristics, the error of determining the range finder distance $\sigma_{D}$ is about $10 \mathrm{~m}$ (Korolov et.al., 2000; Korolov et.al., 2003). Then, using the expression number 4, the object coordinates are determined with an accuracy of $25 \mathrm{~m}$.

Also, applying the correlation number 4 can be made requirements for the accuracy of the devices characteristics in view of the given accuracy of determining the object coordinates.

\section{Conclusions and proposals}

1. The mathematical model of the estimation error estimation of the object coordinates with using the flying platform is proposed.

2. It is shown that the main contribution to the error of determining the object coordinates is given by errors in determining the observation point location and the measurement of range.

3. An analytical correlation is obtained, which allows us to estimate the errors of determining the object coordinates using the flying platform with known errors in determining the observation point coordinates and determining the distance of the range finder.

4. It is shown that for a typical navigation system with accuracy of $20 \mathrm{~m}$ and a range finder with an accuracy of $10 \mathrm{~m}$, the object coordinates are determined with an accuracy of $25 \mathrm{~m}$.

In the future, it is planned to consider the necessary composition of the ground and airborne parts of the equipment and requirements for it.

\section{References}

1. Korolov V., Yakovenko V., Korolova O. Аналіз напрямків та проблем застосування навігаційних технологій у сухопутних військах [Analysis of difficulties and problems associated with technological processes in dry conditions]. VIII Міжнародна науково-технічна конференція "Гіротехнології, навігація, керування рухом та конструювання авіаційно-космічної техніки, 2011, Issue 2, Київ: КПІ, pp. 69-80 (in Ukrainian).

2. Korolov V., Rudenko K., Korolova O. Математична модель оцінки похибок визначення напрямку до рухомої цілі з нерухомого об'єкту координатним способом [Mathematical model of estimation of errors of determination of a direction to a mobile target from a fixed object by a coordinate method]. Сучасні досягнення геодезичної науки та виробництва, 2009, Volume 15, Issue 1, pp. 232-236 (in Ukrainian).

3. Korolov V., Rudenko K., Korolova O. Оцінка похибок визначення координат та вектора швидкості цілі з рухомого об'єкту [Estimation of errors of determination of coordinates and velocity vector of a target from a moving object]. VII Міжнародна науково-технічна конференція "Гіротехнології, навігація, керування рухом та конструювання авіаційно-космічної техніки, 2009, Issue 1, Київ: КПІ, pp. 210-215 (in Ukrainian).

4. Ventcel Е. Теория вероятностей [Probabilite theory]. - Москва: Наука, 1969. - 576 p.(in Russian).

5. Korolov V. Вимоги до характеристик навігаційної інформації і систем навігації наземних рухомих об'єктів в сучасному штатному процесі [Requirements for the characteristics of navigation information and navigation systems for land mobile objects in the modern staffing process]. Сучасні досягнення геодезичної науки та виробництва, 2000, Volume 5, pp. 280-283 (in Ukrainian).

6. Korolov V. Технічні вимоги до навігаційної інформації та сучасних систем навігації наземних рухомих об'єктів [Technical requirements for navigation information and modern navigation systems for land-based mobile objects]. Сучасні досягнення геодезичної науки та виробництва, 2003, Volume 8, pp. 218-221 (in Ukrainian).

Information about authors: 
Volodimir, Korolov, Doctor of Engineering Science, Professor, Leading Researcher of the Research Department Scientific Center of the Ground Forces, National Academy of Land Forces named after Hetman Petro Sakhajdachnyj, 32 Heroes of Maidan street, Lviv, Ukraine, 79026, +380 97241 0296, kvn_lviv@ ukr.net. Navigation systems and complexes (terrestrial and satellite).

Stepan, Savchuk, Doctor of Engineering Science, Professor, Professor of the Department, Department of Higher Geodesy and Astronomy, Lviv Polytechnic National University, Lviv, Ukraine, +380 972133775 , ssavchuk@polynet.lviv.ua. Higher geodesy.

Olha, Korolova, Ph.D. in Engineering Science, Senior Research of the Research Department Scientific Center of the Ground Forces, National Academy of Land Forces named after Hetman Petro Sakhajdachnyj, Lviv, Ukraine , +38067 675 8635, ok_im2@ukr.net. Navigation systems and navigation information sensors.

Ihor, Milkovich, Teacher of the Department, Department of Electromechanics and Electronics, National Academy of Land Forces named after Hetman Petro Sakhajdachnyj, Lviv, Ukraine, +380 666361514 , olya_igor@ukr.net. Navigation systems and navigation information sensors

Yaroslav, Zaec, Senior Research of the Research Department Scientific Center of the Ground Forces, National Academy of Land Forces named after Hetman Petro Sakhajdachnyj, Lviv, Ukraine, +380 663686895 , YG_nc@i.ua. Navigation and geoinformation systems 